PIA 21991

\title{
FISH REMAINS FROM KONAM-RI SHELL MIDDEN SITES, ANMYUN ISLAND, KOREA
}

\section{Deog-im An Institute of Archaeology}

\section{Introduction}

Fish remains recovered from archaeological sites have been studied to reconstruct past human diet, fishing activities, techniques involved in fishing activities, trade and environment (Casteel, 1976; Wheeler, 1978; Brinkhuizen and Clason 1986; Wheeler and Jones, 1989). Identification of fish bones can provide information on the species exploited while the number of individual species exploited can allow us to infer preference in human diet, or the relative contribution of individual species to the diet. A study of the habitats and ecology of fish can provide information on the season of capture, fishing areas and fishing techniques. Fish remains can also be used to estimate fish size, age and weight, season of capture, and so on. A study of selected elements of individual species can be used to infer fish processing techniques and trade activities.

In this paper fish remains from the Konam-ri shell middens on Anmyun Island, Korea, will be studied which will focus on the aspects mentioned above. Sea bream (Chrysophrys major) is one of the species which will be discussed in detail.

Konam-ri shell middens on Anmyun island (fig. 1)

Komam-ri shell middens are located on the Anmyun Island (126 24'E, $3630^{\prime} \mathrm{N}$ ), off the western coast of the central Korean Peninsula.

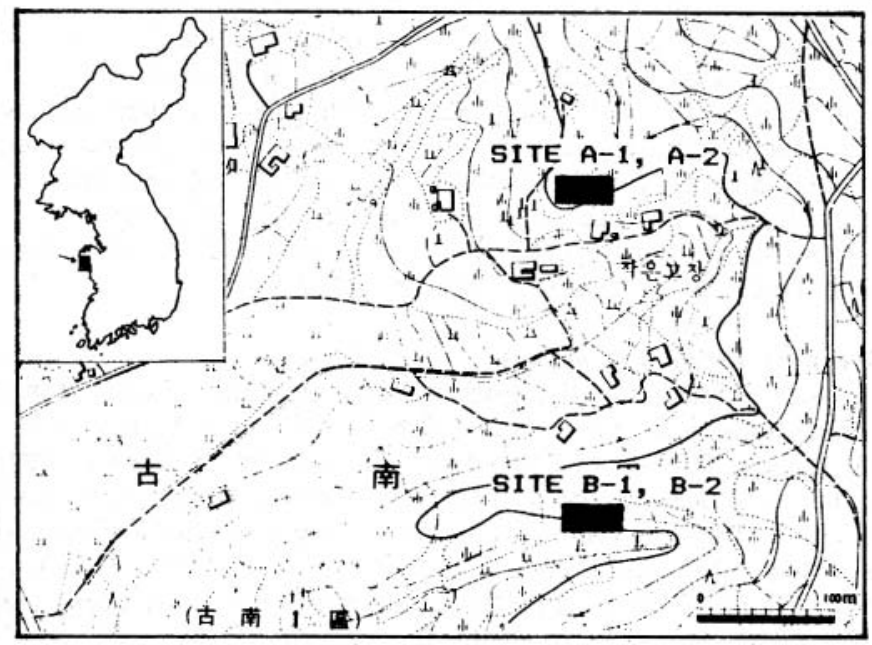

Fig. 1 Distribution map of the Konam-ri shell midden sites 
About 13 shell middens have been discovered on the Island (Kim1983). Two of them (midden complexes A and B) were excavated by the Hanyang University Museum, Seoul, in 1988 and 1989 (Kim and Sim, in press; Kim and An, in press).

The shell midden complexes $\mathrm{A}$ and $\mathrm{B}$ are about $1.5 \mathrm{~km}$ from the sea, but before land reclamation work they might have been much closer. The shell midden complex $A$ is located on a slope (about $25 \mathrm{~m}$ above sea-level) and consists of two shell middens (A-1 and A-2), 1m apart. Midden A-1 dates to the Bronze Age, is circular about $12 \mathrm{~m}$ in diameter and $30-50 \mathrm{~cm}$ thick. Midden A-2, dating to the late Neolithic Period, has almost been destroyed as a result of farming activities.

Midden complex B lies on a southwest facing slope (about $25 \mathrm{~m}$ above sea-level) south of complex A. Complex B consists of two Bronze Age middens (B-1 and B-2 ), 20m apart. Part of these Bronze Age midden deposits has been destroyed by farming activities. Each midden is semi-oval and measures about $13 \mathrm{~m} \times 7.5 \mathrm{~m}$ and $13 \mathrm{~m} \times 5.6 \mathrm{~m}$. The thickest shell deposit of both middens is about $70 \mathrm{~cm}$. Three rectangular dwelling sites were revealed just beneath the middens ( No.1 and No.2 beneath midden B-1 and No.3 beneath midden B-2).

\section{Fish remains}

In the excavations fish bones were recovered by hand, by dry-sieving of the excavated soil using a $3 \mathrm{~mm}$ mesh, and by wet-sieving collected column and bulk samples from the midden deposits in the laboratory. At least 26 different marine fish species have been identified from the fish bones of the Konam-ri shell middens ( Table 1 ). These fish species might have been exploited as food resources. It is possible, however, that very small fish such as anchovy (Engraulis japonicus), from which vertebrae were recovered, might not have been consumed as food. These fish could either have been caught by chance among the larger fish and carried into the midden area, or have come from the removed gut contents of larger fish which had fed on them. Suzuki et.al. (quoted by Suzuki 1989, 102) examined the guts of modem tuna and found small fish bones, from species such as sardine, anchovy and mackerel, which had survived in them. Small fish bones, then, such as anchovy, recovered from shell deposits need not necessarily indicate consumption by humans.

Sea bream, which is abundant among the species, might be regarded as a possible food resource, and is discussed in detail below.

\section{Sea Bream (Chrysophrys major)}

Size estimation of fish from archaeological sites is useful for inferring past fishing activities, as the size of fish captured may be related to fishing methods, tackle, fishing area and season of capture (Akazawa 1969). The estimation of fish size has been attempted by means of dentaries, maxillary or premaxillary bones (Shawcross 1968; Akazawa and Watanabe 1968 ; Akazawa 1969), vertebrae (Casteel 1976; Enghoff 1983) and otoliths (Blacker 1974). Casteel ( 1975 and 1976) also discussed the possibility of estimating size using fish scales. The estimation of sea bream size from the Konam-ri shell midden sites has been attempted using 32 premaxillary bones which were the most abundant and well preserved of all the sea bream bones. The length of the premaxillary bones was measured and compared with the correlation curve 
(fig.2, based on modern specimens) of premaxillary length and fish size, presented by Akazawa ( 1969 ) to estimate the size of sea bream from Jomon shellmounds. The measurements of premaxillary bones from the Konam-ri sites is given in table 2 .

Table 1. List of identified fish species from the Konam-ri sites

\begin{tabular}{llll}
\hline Fish & $\mathbf{A}-\mathbf{1}$ & $\mathbf{B}-1$ & $\mathbf{B ~ - 2}$ \\
\hline Chrysophrys major & $\mathrm{x}$ & $\mathrm{x}$ & $\mathrm{x}$ \\
Achanthopagrus schlegeli & $\mathrm{x}$ & $\mathrm{x}$ & \\
Argyrops bleekeri & & $\mathrm{x}$ & \\
Branchiostegus japonicus & $\mathrm{x}$ & & \\
Taius tumifrons & $\mathrm{x}$ & & \\
Lateolabrax japonicus & $\mathrm{x}$ & $\mathrm{x}$ & $\mathrm{x}$ \\
Bothidae & $\mathrm{x}$ & & \\
Rajiformes & $\mathrm{x}$ & $\mathrm{x}$ & $\mathrm{x}$ \\
Paralichthys olivaceus & $\mathrm{x}$ & $\mathrm{x}$ & $\mathrm{x}$ \\
Holorhinus tobijei & $\mathrm{x}$ & $\mathrm{x}$ & $\mathrm{x}$ \\
Squalidae & $\mathrm{x}$ & $\mathrm{x}$ & \\
Selachimorpha NFI & $\mathrm{x}$ & $\mathrm{x}$ & $\mathrm{x}$ \\
Tetradontidae & $\mathrm{x}$ & $\mathrm{x}$ & $\mathrm{x}$ \\
Fugu pardale & & $\mathrm{x}$ & \\
Sphoeroides rubripes & & $\mathrm{x}$ & \\
Platycephalus indicus & $\mathrm{x}$ & $\mathrm{x}$ & \\
Nibea imbricata & & $\mathrm{x}$ & \\
Ilisha elongata & & $\mathrm{x}$ & \\
Argyrosomus ergentatus & & $\mathrm{x}$ & \\
Astroconger myriaster & & $\mathrm{x}$ & \\
Sardinia melanosticta & $\mathrm{x}$ & $\mathrm{x}$ & $\mathrm{x}$ \\
Engraulis japonicus & $\mathrm{x}$ & $\mathrm{x}$ & $\mathrm{x}$ \\
Mugil cephalus & $\mathrm{x}$ & & \\
Salmonidae & $\mathrm{x}$ & & \\
Chelidonichthys kumu & $\mathrm{x}$ & & \\
Seriolaquinqueradiata & $\mathrm{x}$ & $\mathrm{x}$ & $\mathrm{x}$ \\
unidentified species & $\mathrm{x}$ & &
\end{tabular}

*NFI not further identified. $\mathrm{x}$ : present

Table 2. Measurements of premaxillary length of sea bream from the Konam-ri shell midden sites

\begin{tabular}{llllll}
\hline Pm length $(\mathrm{mm})$ & A-1 & B-1 & B-2 & total & $\%$ \\
\hline $20-24$ & & 3 & & 3 & 9.3 \\
$25-29$ & 2 & 3 & 1 & 6 & 18.8 \\
$30-34$ & 2 & 10 & & 12 & 37.5 \\
$35-39$ & 2 & 3 & 1 & 6 & 18.8 \\
$40-44$ & & 3 & & 3 & 9.3 \\
$45-49$ & & 2 & & 2 & 6.3 \\
& & & & & \\
\hline total & 6 & 24 & 2 & 32 & 100 \\
\hline
\end{tabular}


Measurements of premaxillary length of sea bream from Konam-ri shell midden sites show that their size ranges from $2 \mathrm{~cm}$ to $4.5 \mathrm{~cm}$ with a mean between 3.0 and $3.4 \mathrm{~cm}$. The approximate body length of fish was deduced by using the correlation curve( fig. 2); the composition of presumed body length ranges from about $25 \mathrm{~cm}$ to about $55 \mathrm{~cm}$, with a mean at about $40 \mathrm{~cm}$. It is worth noting that no premaxillary bones smaller than $2 \mathrm{~cm}$ (about $25 \mathrm{~cm}$ body length) have been recovered. This may be related to different preservation rates(smaller bones may disintegrate more easily than bigger ones), sampling bias (bigger bones may be easier to find than smaller ones), fishing methods, fishing tackle, fishing area and season of capture, etc. It is unlikely, however, that all small premaxillary bones would have been destroyed, and it is possible that small fish bones were not exploited. Such selective fishing activities might be related to other factors which are discussed below.

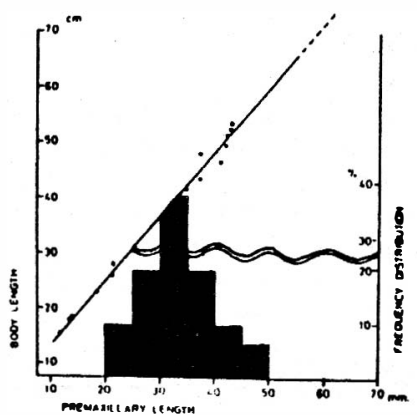

Fig. 2. Correlation curve between body length and premaxillary of sea bream, and histogram of premaxillary length of sea bream from the Konam-ri shell midden sites (Modified from Akazawa 1969, 43.)

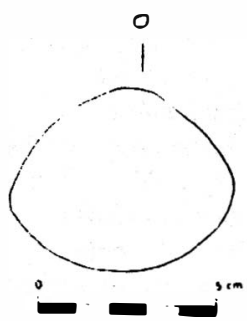

Fig. 3. Shell net-sink from the Konam-ri shell midden

\section{Fishing area and season of capture}

The season of capture can be identified by studying growth rings on fish otoliths and scales(Casteel 1976). It is, however, only possible to identify season of capture when these bones are recovered in a well preserved condition and are studied properly. Seasonality can, however, be inferred from a study of the habitats and behaviour of present-day fish, especially migratory fish species.

Sea bream are deep sea fish, but during the spawning season they migrate close to the shore or coastal areas where they feed until water temperatures become colder in the late autumn or early winter. Small fish feed inshore until they attain adult size ( Akazawa 1969, 46 ). It could be therefore inferred that large fish might be caught between the spawning season and early winter when the fish were inshore or in the coastal area and easily accessible by prehistoric fishermen, even with a relatively undeveloped fishing technology. 
Today sea bream move into the coastal areas of Korea to spawn in May (Chung 1961, 428) and near Anmyun Island are captured between early May and early December, the season peaking between early May and late June and between early September and early December (Chosen Sotokubu 1926, see note 1). It is during this period that the sea bream from the Konam-ri shell middens may have been captured ( in the coastal area or inshore near the Island). The sea bream remains from the sites are of mature individuals, and would have been readily available during their migration to the coastal area. More precise indications of the season of capture will be gained by studying growth rings on fish scales; work on this is currently in progress.

\section{Fishing methods and tackles}

Using ethnographic evidence Brinkhuizen(1983) described three fishing methods: (1) fishing without using tackle; (2) fishing using activelyoperated fishing tackle such as gaffs, rods with a bob, sticks with a noose, spears and lines with a gorge or fish-hooks; and (3) fishing using passivelyoperated fishing gear such as wires, fish-surrounds, fish-traps and fishing nets. However it is difficult to infer the kinds of fishing methods and tackle used in the past because such evidence is not often found.

Two methods, net fishing and angling with fish-hooks, might have been used in this area in the past. The evidence for net fishing is based on a shell sinker(fig.3 ) discovered in site A-1. It is made from a clam shell(Meretrix lamarcki) perforated at the umbo area allowing it to be attached to the net. It is however difficult to prove that the net fishing method was used to catch the sea bream recovered from the sites. The size composition of fish captured by nets depends on the population structure of the target fish, and the mesh size of net used ( Akazawa 1969, 54 ). If fishing activities were carried out in the coastal area during the spawning season and after, as discussed above, it is probable that fish smaller than $25 \mathrm{~cm}$ would have been caught along with bigger fish. But the fact that no remains of fish smaller than $25 \mathrm{~cm}$ in body length have been recovered may indicate selective fishing using a certain size of net mesh, which did not trap small fish. However it is not possible to confirm that sea bream were caught using the net fishing method as there are no remains of nets on the sites.

There is another possibility: that sea bream were caught by angling with fish-hooks. Two fish-hooks made of the canine teeth of wild pig were discovered from site B-1. One is $3.2 \mathrm{~cm}$ in length and $1.6 \mathrm{~cm}$ in width (fig.4); the other, which is broken, is thought to have been of similar size. However, once again, it is difficult to confirm that this fishing tackle was used to catch sea bream.

Experimental work provides information on the relationships between the width of fish-hooks and length of fish caught by using them. It has been shown that the size of fish is selected according to the width of the fishhook; for example, the ratio of the maximum fish mouth width of the most common sized fish captured to the width of the fish-hook used to catch them has been estimated at 0.4 for sea bass, 0.5 for smelt and 0.6 for mackerel (work by Koike et al., quoted by Ishikawa 1985, 77-79 ). However fish smaller or larger than the size most abundantly captured can also be captured by the same fishhook (Ishikawa 1985, 78-79). 


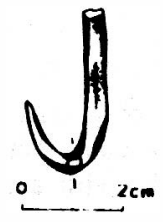

Fig. 4. Fish-hook from the Konam-ri shell midden

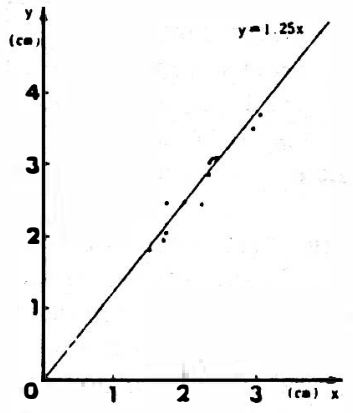

Fig. 5. Correlation curve between the premaxillary length $(x)$ and maximum mouth width $(y)$ of present living sea bream specimens (taken from Ishikawa 1985, 80)

Comparison between the fish-hooks and the remains of sea bream from the Konam-ri sites have been made in an attempt to infer relationships bewteen the two, based on the results of the experimental work mentioned above. The maximum mouth width of the mean size class of premaxillary (3.0$3.4 \mathrm{~cm}$ ) was deduced using the results presented by Ishikawa (1985 79-80), who calculated the maximum mouth width to be 1.25 times the premaxillary length (fig.5). The deduced maximum mouth width of the premaxillary size class (3.0$3.4 \mathrm{~cm}$ ) is about $3.75-4.25 \mathrm{~cm}$. The ratio of the maximum mouth width of the most abundant sea bream size to the width of fish- hooks recovered from the

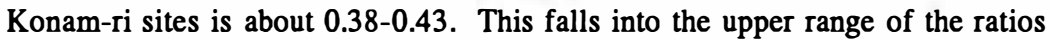
( 0.4-0.6) for the different fish species mentioned above. Although sea bream have not been studied in terms of the relationship between fish-hook width and maximum mouth width, the results from the Konam-ri sites suggests that fishhooks might have been used to catch sea bream.

\section{Conclusion}

In this paper the fish remains from the Konam-ri shell midden sites have been discussed with a detailed study of the remains of sea bream. Sea bream are the most abundant species among the recovered and identified species. The size estimations of the sea bream have been used in an attempt to infer past fishing methods, the fishing tackle used to catch fish, fishing areas and season of catch, etc. It has been inferred that the fish could have been caught during the spawning season and before water temperatures fell in the coastal or inshore areas. A shell sinker might indicate net fishing, but no direct evidence for this has been identified in relation to the capture of sea bream. Fish-hooks might have been used to catch sea bream because the data show the 
ideal ratio between the maximum mouth width of the most common sized fish captured and the width of the fish-hook. Further work is being done on the fish remains, particularly to estimate the precise season of sea bream capture,using the fish scales recovered from the sites.

Note 1. The date given by Choson Sotokubu for the peak fishing period of middle December appears to be a misprint . On the same page (10) the fishing season is given as between early May and early December. The water temperature in middle December is cold and sea bream may have already moved into deep sea. I have therefore used early December.

\section{Acknowledgements}

I would like to thank Dr. Ken Thomas, Norah Moloney and Brian Irving, for their valuable comments and suggestions on an earlier draft of this paper. I am also indebted to Mr. Hiromasa Kaneko, Waseda University in Japan, for his great help with the identification of the fish species.

\section{References}

Akazawa, T. 1969. Body size composition of the fish from the Jomon shellmounds in Japan and its implications in studies on the fishing activities of the Jomon shellmound people. Journal of the Anthropological Society of Nippon,77( 4): 154-78 ( in Japanese with English abstract).

Akazawa, T.\& Watanabe, H. 1968. Restoration of body size of Jomon shellmound fish (Preliminary Report). Proceedings of the VIIIth International Congress of Anthropological and Ethnological Sciences, 3: 193-7. Tokyo.

Blacker, P. W. 1974. Recent advances in otolith studies. In Jones F.R.H.(ed.) Sea Fisheries Research, .67-90. London:Elek Science.

Brinkhuizen, D. C. 1983. Some notes on recent and pre- and protohistoric fishing gear from northwestern Europe, Palaeohistoria 25: 7-53.

Brinkhuizen, D. C. \& Clason, A.T. 1986. Fish and Archaeology. Oxford: B.A.R International Series 294.

Casteel, R. W. 1975. Estimation of size, minimum numbers of individuals, and seasonal dating by means of fish scales from archaeological sites. In Clason, A. T.(ed.) Archaeozoological Studies., .70-86. Amsterdam: North-Holland and New York: American Elsevier.

Casteel, R. W. 1976. Fish Remains in Archaeology and Paleoenvironmental Studies. London: Academic Press.

Chosen Sotokubu. 1926. Chosen Gyogyo Reki (Fisheries Calendar of Chosen, in Japanese).Kyongsong (Seoul).

Chung, M. 1961. Illustrated Encyclopedia the Fauna of Korea (2), Fishes. Seoul: Minister of Education (in Korean ).

Enghoff, I. B. 1983. Size distribution of code (Gadus morhua L.) from a Mesolithic settlement at Vedbaek, North Zealand, Denmark. Videnskabelige Meddelelser fra dansk naturhistorisk Forening , 144: 83-97. 
Ishikawa, T. 1985. About selectivity of angling in Jomon period. Hosei Kokogaku (Joumal of the Hosei Archaeological Society) 10: 68-91 (in Japanese ).

Kim, B. 1983. An archaeological survey on the west coast of the Korean Peninsular, Journal of Korean Archaeological Studies, 14/15: 19-59 (in Korean).

Kim, B. \& Sim, K. The Excavation Report of Konam-ri Shell Midden (I) . Seoul: Hanyang University, The University Museum Research Series No.10 ( in press, in Korean ).

Kim, B. \& An, D. The Excavation Report of Konam-ri Shell Midden (2). Seoul: Hanyang University, The University Museum Research Series No.11. (in press, in Korean with English abstract ).

Shawcross, W. 1968. An investigation of prehistoric diet and economy on a coastal site at Galatea Bay, New Zealand, Proceedings of the Prehistoric Society n.s.33: 107-31.

Suzuki, K. 1989. Kaizuka no Kokogaku (Archaeology of Shell Middens ). Tokyo: University of Tokyo Press ( in Japanese).

Wheeler, A. 1978. Problems of identification and interpretation of archaeological fish remains, In Brothwell, D.R., Thomas, K.D.\& Clutton-Brock, J.(eds.) Research Problems in Zooarchaeology, 6975. London: Institute of Archaeology.

Wheeler, A. \& Jones, A. K. G. 1989. Fishes. Cambridge: Cambridge University Press. 